\title{
Logam Pb pada Avicennia marina Forssk, 1844 (Angiosperms : Acanthaceae) di Lingkungan Air, Sedimen, di Pesisir Timur Semarang
}

\author{
Ega Hagita Testi ${ }^{\star}$, Nirwani Soenardjo, Rini Pramesti \\ Departemen Ilmu Kelautan, Fakultas Perikanan dan IImu Kelautan, Universitas Diponegoro \\ JI. Prof. H. Soedarto S.H, Tembalang,Semarang, Jawa Tengah 50275 Indonesia \\ ${ }^{*}$ Corresponding author, e-mail: e.hagyta@yahoo.com
}

\begin{abstract}
ABSTRAK : Akar Avicennia marina merupakan bagian yang pertama terpapar logam berat timbal. Akar ini menyerap dan menyebarkan keseluruh bagian tanaman. Tujuan dari penelitian ini untuk mengkaji kandungan logam berat $\mathrm{Pb}$ dalam akar dan daun $A$. marina disekitar Kawasan Perairan Industri Terboyo, Semarang. Metode yang digunakan adalah metode deskriptif dan penentuan lokasi dengan metode purposive sampling. Pengambilan sampel meliputi air, sedimen, akar, dan daun mangrove di sepanjang aliran Sungai Sringin, Sungai Babon, dan Sungai Tenggang. Analisis kandungan logam berat di air dilakukan di Laboratorium Balai Lingkungan Hidup (BLH). Analisis kandungan logam berat di sedimen, akar, daun muda dan daun tua dilakukan di Laboratorium Balai Besar Teknologi Pencegahan Pencemaran Industri (BBTPPI) dengan menggunakan Atomic Absorbtion Spectrophotometry (AAS). Kandungan logam berat dalam air $<0,00-0,01 \mathrm{mg} / \mathrm{L}$, sedimen $<0,03-6,23 \mathrm{mg} / \mathrm{kg}$, akar 0,20-0,31 $\mathrm{mg} / \mathrm{kg}$, daun muda $0,10-0,13 \mathrm{mg} / \mathrm{kg}$, dan daun tua 0,10-0,15 $\mathrm{mg} / \mathrm{kg}$. Hasil penelitian dapat disimpulkan bahwa kandungan logam berat di air diatas baku mutu (KepMen LH No. 51, 2004) sebesar 0,008 mg/L sedangkan sedimen dibawah baku mutu (National Oceanic and Atmospheric Administration, 1999) sebesar 30,24 ppm.
\end{abstract}

Kata kunci: Industri, Pb, Akar, Daun, Avicennia marina

\section{Pb in Avicennia marina Forssk, 1844 (Angiosperms: Acanthaceae) in the Water, Sedimentary Environment, on the East Coast of Semarang}

ABSTRACT : The roots of Avicennia marina was a plant that can be accumulated by heavy metals. This plant roots were first exposed to heavy metals, especially heavy metals $\mathrm{Pb}$, was the root. The roots would absorb and spread in all parts of the plant This study was aimed to examine the heavy metal content of $\mathrm{Pb}$ in the roots and leaves of $\mathrm{A}$. marina around Area of Terboyo Industrial Water, Semarang. The method used in this research was descriptive method and the location decision with purposive sampling method. The sampling included were water, sediments, roots, mangrove leaves along Sringin River, Babon River, and Tenggang River. The analysis of heavy metal content in the water was performed in the Laboratory of Environment (BLH). The analysis of heavy metal content in the sediment, the roots, young leaves and old leaves were conducted in Laboratory Technology Center Industrial Pollution Prevention (BBTPPI) using Atomic Absorption Spectrophotometry (AAS). Heavy Metal contained in water $<0,00$ to $0,01 \mathrm{mg} / \mathrm{L}$, sediment $<0,030$ to 6,23 $\mathrm{mg} / \mathrm{kg}$, the roots of $A$. marina were 0,20 to $0,31 \mathrm{mg} / \mathrm{kg}$, the young leaves were 0,10 to $0,13 \mathrm{mg} / \mathrm{kg}$, and the old leaves 0,10 to $0,15 \mathrm{mg} / \mathrm{kg}$. the result of this research can be concluded that the heavy metal content in water were high quality standard (KepMen LH No. 51, 2004) of 0,008 mg/L and in sediments below was under quality standard in (National Oceanic and Atmospheric Administration, 1999) of 30,24 ppm.

Keywords: Industrial, Lead, Roots, Leaves, Avicennia marina

\section{PENDAHULUAN}

Kawasan perairan Terboyo Semarang merupakan kawasan yang dialiri oleh 3 aliran sungai, yang meliputi: Sungai Sringin (berdekatan dengan aktivitas pemukiman), Sungai Babon (berdekatan dengan aktivitas Industri), dan Sungai Tenggang (berdekatan dengan pertambakan dan aktivitas nelayan). Kawasan ini terdapat beberapa industri disekitarnya yang diduga limbah buangannya dapat mencemari lingkungan sekitar perairan. Perairan yang tercemar akan 
berdampak pada biota dan tumbuhan pesisir seperti mangrove. Sesuai penelitian Kartikasari (2002) yang menyatakan bahwa sungai sringin dan sungai babon telah tercemar adanya logam berat $\mathrm{Pb}$. Hal ini diduga dapat berdampak pada ekosistem perairan sekitar, khususnya ekosistem mangrove.

Jenis mangrove yang tumbuh di kawasan ini meliputi Rhizophora mucronata, Acanthus ilicifolius, Bruguiera gymnorrhiza, dan Avicennia marina. A. marina merupakan salah satu jenis mangrove yang sering ditemukan di kawasan tersebut dan memiliki fungsi dalam melemahkan efek racun melalui pengenceran, yaitu dengan cara menyimpan air untuk mengencerkan konsentrasi logam berat dalam jaringan tubuhnya sehingga dapat mengurangi toksisitas dalam logam berat. Subowo et al. (1999) logam berat adalah unsur logam yang mempunyai massa jenis lebih besar dari $5 \mathrm{~g} / \mathrm{cm} 3$. Logam berat $\mathrm{Pb}$ merupakan salah satu unsur logam yang bersifat tidak dapat terurai (non degradable) dan mudah diabsorbsi. Diperkuat Hutagalung et al.(1997) bahwa logam berat dalam air ditemukan dalam bentuk terlarut dan tersuspensi. Logam berat dalam air yang terjadi disebabkan oleh masuknya limbah domestik, industri, pertambakan dan aktivitas nelayan yang mengandung logam berat.

Fitter (1982) mekanisme tumbuhan mangrove $A$. marina dalam menghadapi konsentrasi polutan yang tinggi di sekitarnya adalah dengan teknik ameliorasi dan toleransi. Ameliorasi yaitu meminimumkan pengaruh toksin yang dilakukan dengan melokalisasi toksin pada organ tertentu, misalnya akar. Teknik ameliorasi dilakukan dengan dua cara yaitu ekskresi dan dilusi. Ekskresi yaitu mekanisme pada tumbuhan dengan cara mengeluarkan toksin secara aktif melalui kelenjar tajuk atau secara pasif melalui akumulasi pada daun - daun tua yang diikuti dengan pengguguran daun. Dilusi yaitu melemahkan efek toksin melalui pengenceran dan inaktivasi toksin secara kimia.

Adaptasi $A$. marina terhadap lingkungan yang tercemar juga dapat dilakukan dengan cara toleransi. Toleransi dilakukan dengan mengembangkan sistem metabolik yang dapat berfungsi pada lingkungan dengan konsentrasi toksik yang tinggi.

Akar A. marina merupakan bagian yang pertama terpapar oleh logam berat $\mathrm{Pb}$. Akar ini mampu menyerap dan menyebarkan keseluruh tanaman. Daun yang pertama terpapar oleh logam berat $\mathrm{Pb}$ adalah daun tua selanjutnya bagian daun muda. Berdasarkan hal tersebut mangrove jenis $A$. marina dapat dikatakan memiliki kemampuan dalam mengakumulasi logam berat $\mathrm{Pb}$ melalui akar, kemudian menyebar ke seluruh bagian tumbuhan termasuk daun. Apabila bagian daun telah terdeteksi logam berat $\mathrm{Pb}$ diduga logam berat juga menyebar sampai ke buah. Penelitian di kawasan Sungai Sringin, Sungai Babon, Sungai Tenggang perlu dilakukan guna mengkaji "Kandungan logam berat Timbal $(\mathrm{Pb})$ yang terdapat di dalam air, sedimen, akar, daun muda dan daun tua mangrove $A$. marina".

\section{MATERI DAN METODE}

Materi yang digunakan sampel air, sedimen, akar, daun muda dan daun tua mangrove $A$. marina. Penelitian ini dilakukan pada Bulan Juli - Agustus 2015. Penentuan lokasi dengan Purposive Sampling menggunakan alat bantu GPS (Global Positioning System). Lokasi pengambilan sampel meliputi sepanjang aliran Sungai Sringin (dekat pemukiman), Sungai Babon (dekat aktivitas industri), dan Sungai Tenggang (dekat tambak dan aktivitas nelayan). Metode yang digunakan dengan metode deskriptif dan lokasi penelitian disajikan pada Gambar 1.

Analisis air dilakukan di Laboratorium Balai Lingkungan Hidup (Semarang). Analisis kandungan logam berat $\mathrm{Pb}$ yang berasal dari sedimen, akar, daun muda dan daun tua mangrove A. marina dilakukan di Laboratorium Balai Besar Teknologi Pencegahan Pencemaran Industri (BBTPPI).

Sampel air yang diperoleh merupakan sampel perwakilan dari tiap stasiun. Masing masing stasiun terdapat 3 kali pengulangan, dan diperoleh sampel sebanyak 5 liter dari setiap stasiun. Sampel tersebut kemudian diberi label dan diberi larutan $\mathrm{HNO}_{3}$ yang berfungsi sebagai pengikat logam berat (Rochyatun et al., 2010). Sampel air kemudian dianalisis kandungan logam berat $\mathrm{Pb}$ dengan metode AAS (Atomic Absorption Spectrophotometer).

Sampel sedimen diambil secara insitu dengan menggunakan pipa paralon yang dimodifikasi. Pipa tersebut berdiameter $\pm 5 \mathrm{~cm}$ dengan panjang $\pm 30 \mathrm{~cm}$. Sampel sedimen diambil di setiap stasiun dengan tiga kali ulangan dengan kedalaman $\pm 30 \mathrm{~cm}$ dan sebanyak $1 \mathrm{~kg}$. Sampel 
tersebut dijadikan 1 , kemudian diambil $1 \mathrm{~kg}$ sebagai sampel perwakilan dari tiap stasiun. Sampel sedimen kemudian dibawa ke laboratorium untuk dilakukan analisis kandungan Timbal dengan metode AAS (Atomic Absorption Spectrophotometer)

Sampel akar $A$. marina merupakan bagian pangkal akar yang berada di dalam substrat dan diambil dengan ukuran panjang $\pm 10 \mathrm{~cm}$ (Johansen, 1940). Sampel ini diperoleh dari masing masing stasiun dengan 3 kali pengulangan, sehingga diperoleh sebanyak $\pm 250 \mathrm{~g}$ untuk setiap stasiun. Sampel tersebut kemudian dianalisis kandungan logam berat $\mathrm{Pb}$ dengan metode AAS (Atomic Absorption Spectrophotometer). Pengambilan sampel daun A. marina dilakukan dengan menggunakan tangan dan dilakukan dengan metode pengulangan. Sampel daun yang diambil merupakan daun muda dan daun tua. Daun muda terletak di ujung dahan, berwarna hijau terang, lunak dan lemas, sedangkan daun tua terletak di bagian belakang dahan, warnanya lebih gelap, teksturnya lebih kasar (Cooke et al., 1984; Fransworth dan Ellison, 1991; Nascimento dan Hay, 1993; Pribadi, 1998).

Pengambilan sampel daun muda dan daun tua bertujuan untuk mengetahui ada atau tidaknya perbedaan dalam melakukan penyerapan logam berat $\mathrm{Pb}$. Sampel daun yang diperoleh sebanyak $\pm 250 \mathrm{~g}$ untuk daun muda dan $\pm 250 \mathrm{~g}$ untuk daun tua. Masing - masing sampel daun kemudian dijadikan 1 dan selanjutnya diambil sebanyak $\pm 250 \mathrm{~g}$ sebagai sampel perwakilan dari setiap stasiun. Sampel daun kemudian dibawa ke laboratorium dan dilakukan analisis kandungan Timbal dengan metode AAS (Atomic Absorption Spectrophotometer).

Data yang diperoleh meliputi data kandungan logam berat $\mathrm{Pb}$ dalam air, sedimen, akar, daun muda dan daun tua mangrove $A$. marina serta parameter lingkungan yang dianalisis secara deskriptif.

Hasil kandungan logam berat $\mathrm{Pb}$ yang diperoleh kemudian dibandingkan dengan baku mutu yang ditetapkan oleh KepMen LH No. 51, 2004 untuk perairan sebesar 0,008 mg/L, sedangkan menurut Buchman (1999) sedimen dibandingkan dengan ketetapan National Oceanic and Atmospheric Administration sebesar 30,24 ppm.

Sampel yang telah diketahui kandungan logam berat $\mathrm{Pb}$ kemudian dianalisis dengan perhitungan faktor translokasi (TF). Perhitungan ini dilakukan untuk mengetahui kemampuan $A$. marina dalam mentranslokasikan logam berat $\mathrm{Pb}$ dari akar ke daun. Konsentrasi logam berat $\mathrm{Pb}$ di bagian akar dan daun dapat diketahui dengan perhitungan faktor biokonsentrasi (BCF) (MacFarlane et al., 2007). Rumus perhitungan faktor translokasi (TF) dan faktor biokonsentrasi (BCF) sebagai berikut: BCF $<250$ Kemampuan Rendah; $1000 \geq B C F \geq 250=$ Kemapuan Sedang; Jika nilai BCF $>1000=$ Kemampuan Tinggi.

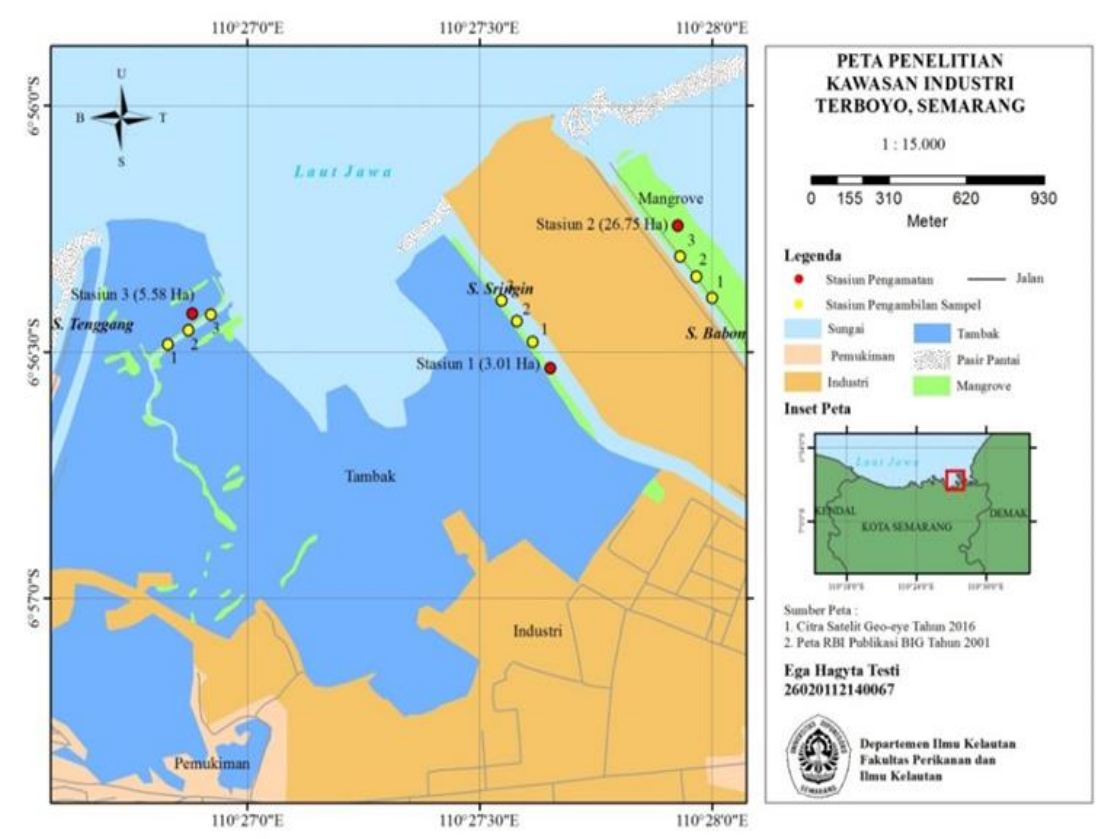

Gambar 1. Lokasi pengambilan sampel air, sedimen, akar, daun muda dan daun tua A. marina. 


\section{HASIL DAN PEMBAHASAN}

Pengukuran parameter lingkungan dilakukan secara insitu yaitu langsung di lapangan. Pengukuran dilakukan sebanyak 3 kali pengulangan. Hasil dari pengukuran parameter lingkungan disajikan pada Tabel 1. Hasil pengukuran parameter lingkungan menunjukan nilai Suhu tertinggi berada di Stasiun 1 dan Stasiun 2 yaitu $27^{\circ} \mathrm{C}$, nilai DO tertinggi berada di Stasiun 3 yaitu 6,8 mg/L, nilai $\mathrm{pH}$ pada ketiga Stasiun bernilai sama yaitu 7. Nilai salinitas tertinggi berada di Stasiun 2 sebesar $23 \%$. Hasil analisis kandungan logam berat pada air, sedimen, akar, daun muda dan daun tua A. marina disajikan pada Tabel 2.

Kandungan logam $\mathrm{Pb}$ tertinggi dalam air terdapat di stasiun 1 (Sungai Sringin) dan stasiun 2 (Sungai Babon). Hal ini diduga adanya pengaruh peningkatan suhu dapat menyebabkan peningkatan kecepatan metabolisme dan meningkatkan konsumsi oksigen. Kondisi tersebut sesuai dengan pendapat Effendi (2003) bahwa kenaikan suhu perairan juga berdampak atau mempengaruhi konsentrasi kadar logam berat pada perairan tersebut. Diperkuat oleh pendapat

Tabel 1. Hasil pengukuran parameter lingkungan di Kawasan Perairan Industri Terboyo, Semarang

\begin{tabular}{cccc}
\hline Parameter & Titik Sampling & Hasil Pengukuran & $\begin{array}{c}\text { Baku Mutu } \\
\text { KepmenLH No 51 Tahun 2004 }\end{array}$ \\
\hline Suhu $\left({ }^{\circ} \mathrm{C}\right)$ & Stasiun 1 & 27 & $28-30$ \\
& Stasiun 2 & 27 & \\
$\mathrm{pH}$ & Stasiun 3 & 26 & $6-8$ \\
& Stasiun 1 & 7 & 5 \\
$\mathrm{DO}(\mathrm{mg} / \mathrm{L})$ & Stasiun 2 & 7 & \\
& Stasiun 3 & 7 & \\
Salinitas $(\%$ oo $)$ & Stasiun 1 & 6,6 & 35 \\
& Stasiun 2 & 6,7 & \\
& Stasiun 3 & 6,8 & \\
& Stasiun 1 & 19 & \\
& Stasiun 2 & 23 & \\
& Stasiun 3 & 20 & \\
\hline
\end{tabular}

Tabel 2. Hasil kandungan logam berat Timbal $(\mathrm{Pb})$ pada air, sedimen, akar, daun muda dan daun tua $A$. marina di Kawasan Perairan Industri Terboyo, Semarang.

\begin{tabular}{cccc}
\hline Parameter & Titik Sampling & Hasil & Baku Mutu \\
\hline Air $(\mathrm{mg} / \mathrm{L})$ & Stasiun 1 & 0,01 & 0,008 \\
& Stasiun 2 & 0,01 & \\
& Stasiun 3 & $<0,00$ & 30,24 \\
Sedimen $(\mathrm{mg} / \mathrm{kg})$ & Stasiun 1 & $<0,03$ & \\
& Stasiun 2 & 6,23 & \\
Akar $(\mathrm{mg} / \mathrm{kg})$ & Stasiun 3 & 4,05 & \\
& Stasiun 1 & 0,31 & \\
& Stasiun 2 & 0,20 & \\
Daun Muda $(\mathrm{mg} / \mathrm{kg})$ & Stasiun 3 & 0,22 & \\
& Stasiun 1 & 0,10 & \\
& Stasiun 2 & 0,13 & \\
Daun Tua $(\mathrm{mg} / \mathrm{kg})$ & Stasiun 3 & 0,10 & \\
& Stasiun 1 & 0,10 & \\
& Stasiun 2 & 0,15 & \\
\hline Keterangan: ${ }^{*}=$ Baku mutu & Sir KepmenLH No 51 Tahun $2004 ;{ }^{* *}=$ Sedimen Berdasarkan NOAA \\
(Buchman, 1999$).$ & & & \\
\end{tabular}


Hutagalung (1984) ; Snedaker (1978) kenaikan suhu tidak hanya akan meningkatkan metabolisme biota perairan, tetapi juga dapat meningkatkan toksisitas logam berat perairan. Peningkatan suhu selain dapat meningkatkan daya racun logam berat terhadap organisme perairan.

Hasil pengukuran parameter pH di stasiun 1,2 dan 3 menunjukkan nilai yang sama yaitu 7 (netral). Hawkes (1978) dan Palar (1994) menyatakan bahwa nilai pH yang lebih dari 9 dapat berpengaruh dalam meningkatkan toksisitas logam berat. Hal ini disebabkan ion logam membentuk senyawa kompleks dengan senyawa lain sehingga akan mengendap di dasar perairan bersama sedimen. Penurunan kandungan logam berat $\mathrm{Pb}$ terjadi karena adanya faktor dari oksigen terlarut. Oksigen terlarut merupakan unsur bagi kehidupan yang berperan dalam proses biologi di lautan. Hilangnya oksigen terlarut dalam perairan selain karena respirasi tumbuhan dan hewan juga karena dimanfaatkan oleh mikroba.

Mance (1987) menyatakan bahwa nilai salinitas yang lebih dari 35 (\%) dapat berpengaruh terhadap logam berat di perairan karena semakin tinggi salinitas maka akan menyebabkan konsentrasi logam berat dalam perairan berkurang. Selain itu terdapat adanya reaksi antara ion logam tersebut dengan ion klorida. Sesuai dengan hasil analisis Sahara (2009) kandungan logam berat ditemukan lebih tinggi di dalam sedimen yang berbentuk lumpur berlempung. Kandungan logam berat $\mathrm{Pb}$ yang mengendap dalam sedimen memiliki tekstur pori yang cukup kecil dan daya absorbsi yang cukup tinggi sehingga kadar logam berat yang didapat cukup tinggi. Logam berat yang masuk ke dalam lingkungan perairan akan mengalami pengendapan, pengenceran dan dispersi, kemudian diserap oleh organisme yang hidup di perairan tersebut (Hutagalung, 1984).

Kandungan logam berat $\mathrm{Pb}$ di akar pada stasiun 1 (Sungai Sringin) besar dibandingkan stasiun 2 (Sungai Babon) dan stasiun 3 (Sungai Tenggang). Hal ini diduga logam $\mathrm{Pb}$ pada akar di stasiun 1 (Sungai Sringin) telah terserap oleh akar. Penyerapan logam berat akan membentuk suatu enzim reduktase di membran akarnya. Reduktase ini berfungsi mereduksi logam yang selanjutnya diangkut melalui mekanisme khusus di dalam membran akar. Menurut Rossiana (2003) bahwa akan terjadi translokasi di dalam tubuh tanaman, logam yang masuk ke dalam sel akar, selanjutnya diangkut ke bagian tumbuhan yang lain melalui jaringan pengangkut yaitu $x y l e m$ dan floem. Akumulasi logam $\mathrm{Pb}$ pada akar tanaman melalui bantuan transpor liquid dalam membran akar, akan membentuk transpor logam kompleks yang akan menembus xylem dan menuju ke sel daun tanaman. Yoon et al. (2006) akar juga memiliki sistem penghentian transpor logam menuju daun terutama logam non - esensial, sehingga terjadi adanya penumpukkan logam berat $\mathrm{Pb}$ di bagian akar. Lindangwati (2011) menambahkan bahwa kandungan logam berat $\mathrm{Pb}$ di bagian akar $A$. marina dipengaruhi oleh beberapa faktor yaitu : (a) kadar logam $\mathrm{Pb}$ dalam sedimen atau substrat, (b) morfologi dan fisiologi tumbuhan, (c) umur tumbuhan, dan (d) jenis tumbuhan yang hidup diperairan tersebut.

Tanaman $A$. marina tidak hanya menunjukkan akumulasi logam berat $\mathrm{Pb}$ di bagian akar melainkan juga terdapat di bagian daun. Akumulasi logam berat yang telah sampai pada daun selanjutnya akan melewati plasmalema, sitoplasma, dan vakuola, dimana logam $\mathrm{Pb}$ akan terakumulasi dalam vakuola yang tidak akan berhubungan dengan proses fisiologi sel tumbuhan (Haryati, 2012).

Kandungan logam berat $\mathrm{Pb}$ pada daun tua memiliki hasil yang lebih besar dibandingkan daun muda. Hal ini diduga adanya perbedaan periode waktu yang terjadi dalam penyerapan logam berat $\mathrm{Pb}$ oleh daun tua ataupun daun muda. Periode waktu yang dimaksud adalah ketika daun tua mengalami pertumbuhan yang sudah sempurna, sehingga penyerapan logam berat lebih tinggi dibandingkan dengan daun muda. Kanvel (2013) menjelaskan kandungan logam berat $\mathrm{Pb}$ yang terdapat di daun muda lebih sedikit dibandingkan dengan daun tua hal ini dikarenakan daun muda akan lebih sulit dalam menyerap logam $\mathrm{Pb}$ dari pada daun yang sudah tua.

\section{Nilai Faktor Biokonsentrasi (BCF)}

Nilai Biokonsentrasi (BCF) akar dan daun dihitung untuk mengetahui konsentrasi logam berat $\mathrm{Pb}$ yang berasal dari lingkungan sekitar. Nilai Faktor Biokonsentrasi (BCF) disajikan pada Tabel 3. Penghitungan nilai BCF tertinggi dalam daun muda dan daun tua terdapat di stasiun 1 sebesar 3,3 dan terendah terdapat pada akar di stasiun 1 sebesar $<10,33$. Hal ini diduga karena 
adanya perbedaan dalam penyerapan. Tingginya kandungan logam berat $\mathrm{Pb}$ di jaringan tanaman menyebabkan berkurangnya kadar klorofil daun, yang mempengaruhi proses fotosintesis dan berdampak pada berkurangnya hasil produksi dari suatu tumbuhan. Hal ini sesuai dengan Gothberg (2008) menyatakan bahwa logam berat $\mathrm{Pb}$ yang terdapat dalam jaringan tanaman dapat mempengaruhi proses dari fotosintesis.

\section{Nilai Faktor Translokasi (TF)}

Perhitungan Faktor Translokasi (TF) dilakukan untuk mengetahui seberapa besar kemampuan dari $A$. marina dalam mentranslokasikan logam berat $\mathrm{Pb}$ dari akar ke daun (MacFarlane et al., 2007). Nilai Faktor Translokasi (TF) disajikan pada Tabel 4. Hasil penelitian menunjukkan nilai translokasi faktor (TF) tertinggi terdapat pada stasiun 2 (Sungai Babon) sebesar 0,75 untuk daun tua dan 0,65 untuk daun muda. Masuknya partikel $\mathrm{Pb}$ ke dalam jaringan daun diduga dipengaruhi oleh ukuran dan jumlah dari stomata. Semakin besar ukuran dan semakin banyak jumlah stomatanya maka semakin besar pula penyerapan timbal yang masuk ke dalam daun. Smith (1981) mekanisme masuknya paertikel Pb ke dalam jaringan daun berlangsung secara pasif, tetapi akumulasi timbal di dalam jaringan daun akan lebih besar. Logam berat $\mathrm{Pb}$ ini akan terakumulasi di dalam jaringan palisade (jaringan pagar). Partikel akan masuk ke dalam daun lewat celah stomata serta menetap dalam jaringan daun dan menumpuk di antara celah sel jaringan pagar / palisade.

Tabel 3. Nilai Faktor Biokonsentrasi (BCF)

\begin{tabular}{cccc}
\hline Titik Sampling & Akar & Daun Tua & Daun Muda \\
\hline Stasiun 1 & $<10,33$ & 3,30 & 3,30 \\
Stasiun 2 & 0,03 & 0,02 & 0,02 \\
Stasiun 3 & 0,05 & 0,02 & 0,02 \\
\hline
\end{tabular}

Tabel 4. Nilai Faktor Translokasi (TF) Logam Berat Timbal (Pb).

\begin{tabular}{ccc}
\hline Titik Sampling & Daun Tua & Daun Muda \\
\hline Stasiun 1 & 0,32 & 0,32 \\
Stasiun 2 & 0,75 & 0,65 \\
Stasiun 3 & 0,45 & 0,45 \\
\hline
\end{tabular}

\section{KESIMPULAN}

Hasil kandungan logam berat $\mathrm{Pb}$ dalam sedimen lebih tinggi dibandingkan pada kolom perairan, sedangkan sampel akar diperoleh hasil lebih tinggi dibandingkan dengan daun muda dan daun tua

\section{DAFTAR PUSTAKA}

Buchman, M. 1999. Ilmu Tanah. Gajah Mada University Press, Yogyakarta.

Cooke, F.P., Brown, J.P. \& Mole, S. 1984. Herbivory Enzym Inhibitors, Nigtrogen and Leaf Structure of Young and Mature Leaves in A Tropical Forest. Biotropica, 16(4):257-263.

Effendi, H. 2003. Telaah Kualitas Air Bagi Pengelolaan Sumberdaya dan Lingkungan Perairan. Kanisius, Yogyakarta. $258 \mathrm{hlm}$.

Fitter. 1982. Fisiologi Lingkungan Tanaman. Gajah Mada University Press. Yogyakarta.

Fransworth, E.J. \& Ellison, A.M. 1991. Pattern of Herbivory in Belizean mangrove Swamps. Biotropica, 23(4b):555-567. 
Gothberg, A. 2008. Metal Fate and Sensitivity In The Aquatic Tropical Vegetable Ipomea Aquatica.Departement of Applied Enviromental Science. Stockholm University. pp 1-39.

Haryati, M., Purnomo, T. \& Kuntjoro, S. 2012. Kemampuan Tanaman Genjer (Limnocharis Flava (L.)Buch.) Menyerap Logam Berat Timbal (Pb) Limbah Cair Kertas pada Biomassa dan Waktu Pemaparan yang Berbeda. LenteraBio, 1(3):131-138.

Hawkes, T. 1978. Structuralism and Semiotics. London: Methuen and Co. Ltd.

Hutagalung. 1984. Logam Berat Dalam Lingkungan Laut. Pewarta Oceana 9(1):12-1.

Jeon, Y.K., Lee, B.Y., Kim, J.E., Lee, S.S. \& Kim, C.W., 2004. Molecular characterization of epstein-barr virus and oncoprotein expression in nasopharyngeal carcinoma in Korea. Head \& Neck: Journal for the Sciences and Specialties of the Head and Neck, 26(7):573-583.

Johansen, D.A. 1940. Plant Microtechnique. McGraw - Hill Book Company. New York.

Kanvel, P.S. 2013. Akumulasi Logam Berat Tembaga $(\mathrm{Cu})$ dan Timbal $(\mathrm{Pb})$ pada Pohon Rhizophora mucronata di Hutan Mangrove Desa Nelayan Kecamatan Medan Labuhan dan Desa Jaring Halus Kecamatan Secanggang. Skripsi. Jurusan Budidaya Hutan. Universitas Sumatera Utara. Medan.

Kartikasari, V., Tandjung, S.D. \& Sunarto. 2002. Akumulasi Logam $\mathrm{Cr}$ dan Pb Pada Pertumbuhan Mangrove Avicennia marina Di Muara Sungai Babon Dan Sungai Sringin Perbatasan Kota Semarang Dan Kabupaten Demak Jawa Tengah. Manusia dan Lingkungan. 9(3):137-147

Keputusan Menteri Negara Lingkungan Hidup. 2004. Keputusan Menteri Negara Lingkungan Hidup No: 51/MNKLH/1/2004 tentang pedoman penetapan baku mutu air laut. Menteri Lingkungan Hidup. Jakarta. 6-7 hlm.

Lindangwati. 2011. Bioakumulasi Logam Berat Timbal (Pb) pada Mangrove Avicennia marina di Sungai Tapak dan Sungai Seringin (Semarang) dan Semat (Jepara). Fakultas Perikanan dan IImu Kelautan. Universitas Diponegoro. Semarang.

Mac Farlane, G.R., Koller, E.C. \& Blomberg, S.P.. 2007. Accumulation and Patitioning of Heavy Metals in Mangrove: A Synthesis of Field-based Studies. Chemosphere, 69(9):1454-1464.

Mance, G., 2012. Pollution threat of heavy metals in aquatic environments. Springer Science \& Business Media.

Nascimento.M.T \& Hay, J.D. 1993. Intraspesific Variation in Herbivory on Metrodorea pubescens (Rutacea) in Two Forest Type in Central Brazil. Revista Brasileira de Biologia 53:143-153.

Palar, H. 1994. Pencemaran dan Toksikologi Logam Berat. PT. Rineka Cipta. Jakarta.

Pribadi, R. 1998. The Ecology of Mangrove Vegetation in Bintuni Bay, Irian Jaya, Indonesia. Departement of Biological and Molecular Sciences University of Stirling. pp53-54.

Rochyatun, E., Kaisupy, M.T. \& Rozak, A.. 2010. Distribusi Logam Berat dalam Air dan Sedimen di Perairan Muara Sungai Cisadane. Makara Sains, 10(1):35-40

Rossiana, N. 2003. Penurunan Kandungan Logam Berat Dan Pertumbuhan Tanaman Sengon (Paraserianthes falcataria L. (Nielsen)) Bermikoriza Dalam Medium Limbah Lumpur Minyak Hasil Ekstraksi. Universitas Padjadjaran. Bandung.

Sahara, E. 2009. Distribusi $\mathrm{Pb}$ dan $\mathrm{Cu}$ pada berbagai ukuran partikel Sedimen di Pelabuhan Benoa. Bali. Jurnal Kimia, 3(3):75-80.

Smith, J.M. 1981. Chemical Engineering Kinetics. 3 ed. Mc.Graw Hill Book Company. Inc. New York.

Snedaker, S.C., 1978. Mangroves: Their Value and Perpetuation. Nature and Resources,14:6-13.

Subowo, Subaga, J. \& Sudjadi, M. 1997. Pengaruh bahan organik terhadap pencucian hara tanah Ultisol Rangkasbitung, Jawa Barat. Pemberitaan Penelitian Tanah dan Pupuk, 9:26-31. 